\title{
KEHARMONISAN KELUARGA TENAGA KERJA WANITA PERSPEKTIF PSIKOLOGI KELUARGA ISLAM
}

\author{
Umi Rohmawati ${ }^{*}$ Ika Rusdiana ${ }^{2 *}$ \\ 1,2 Fakultas Syariah, IAIN Ponorogo \\ ${ }^{1}$ Email: umirohma89@gmail.com \\ 2Email: rosdyana.ika@gmail.com
}

\begin{tabular}{c|c|c}
\hline \multicolumn{3}{l}{ DOI:- } \\
\hline Received: $30-7-2021$ & Revised: 21-8-2021 & Approved: 3-9-2021 \\
\hline
\end{tabular}

Abstract: Nowadays, due to the complex family economic problems, it is the reason for a wife to become a TKW abroad to improve the family's economy. This study aimed to determine the psychological analysis of Islamic families on the communication patterns of TKW families and to find out the psychological analysis of Islamic families on conflict resolution in TKW families from Gajah Village Ponorogo. The method used a qualitative method with data collection techniques with interviews and documentation. The results showed that the communication pattern of the TKW families in Gajah Village was by the Qur'an about communication ethics, namely: trustworthy, not lying, and fair. Conflict resolution in realizing a harmonious family in the TKW family in Gajah Village uses four conflict resolutions contained in QS an-Nisa' verse 35, namely: al-Ma'ruf (tenderness and harmony between husband and wife), al-Ma'ruf (tenderness and harmony between husband and wife), al-Sabru (patience), Tahammul al-Ada (freedom in conveying and receiving partner's opinion) and al-Wa'zu (advice).

Keywords: Islamic Family Psychology, The Family Harmony, TKW.

Abstrak: Pada zaman sekarang karena problematika ekonomi keluarga yang kompleks, menjadi alasan seorang istri untuk menjadi TKW di luar negeri dengan tujuan memperbaiki ekonomi keluarga. Tujuan penelitian ini untuk mengetahui analisis psikologi keluarga Islam terhadap pola komunikasi keluarga TKW dan untuk mengetahui analisis psikologi keluarga Islam terhadap resolusi konflik dalam keluarga TKW di Desa Gajah Ponorogo. Metode yang digunakan dalam penelitian ini adalah metode kualitatif dengan teknik pengumpulan data dengan wawancara dan dokumentasi. Hasil penelitian menunjukkan bahwa pola komunikasi pada keluarga TKW di Desa Gajah sesuai dengan al-Qur'an tentang etika berkomunikasi, yaitu: amanah, tidak melakukan dusta dan adil. Resolusi konflik dalam mewujudkan keluarga yang harmonis pada keluarga TKW di Desa Gajah menggunakan 4 resolusi konflik yang terdapat dalam QS an-Nisá' ayat 35, yaitu: alMa'rüf (kelembutan dan kerukunan antara suami dan istri), al-Sabru (kesabaran), Tahammul al-Ada (kebebasan dalam menyampaikan dan menerima pendapat pasangan) dan al-Wa'zu (nasehat).

Kata Kunci: Keharmonisan Keluarga, Psikologi Keluarga Islam, TKW. 


\section{PENDAHULUAN}

Keluarga adalah suatu ikatan laki-laki dengan perempuan berdasarkan hukum dan undang-undang perkawinan yang sah. ${ }^{1}$ Struktur keluarga terdapat dua macam, yakni keluarga inti dan keluarga batih, yaitu keluarga yang bercabang, keluarga berumpun dan keluarga beranting. Struktur keluarga tidak ditentukan oleh jumlah orang yang berada di dalamnya, akan tetapi ditentukan oleh banyaknya posisi sosial yang terdapat dalam keluarga. ${ }^{2}$ Keluarga yang baik adalah keluarga yang mampu menjalankan peran masing-masing anggota keluarga. Seorang suami atau ayah memiliki peran sebagai pemimpin, ia wajib memenuhi kebutuhan pokok dalam rumah tangga, baik kebutuhan material maupun spiritual. Adapun seorang istri atau ibu memiliki peran rabbah al-bayt (pengelola rumah tangga). ${ }^{3}$ Akan tetapi pada zaman sekarang karena problematika ekonomi yang kompleks, kebutuhan dan keperluan keluarga semakin meningkat. Hal tersebut menjadi alasan istri untuk menjadi TKW. Dalam Islam pun tidak melarang seseorang bekerja di manapun asalkan pekerjaan itu halal. Islam merupakan agama yang menjunjung tinggi prinsip rahmat lil 'alamin yang berarti Islam menjadi payung bagi seluruh apa yang ada di alam ini. ${ }^{4}$

Meskipun secara fisik kehidupan mereka tidak bersama keluarga masingmasing, dalam keluarga TKW tersebut tidak menutup kemungkinan terjadi sebuah konflik yang menyebabkan perceraian. Peneliti mengambil data perceraian dari Pengadilan Agama Kabupaten Ponorogo sejak tahun 2019 terdapat 451 perkara cerai gugat yang didominasi oleh pekerja migran. ${ }^{5}$ Data perceraian tersebut dilatarbelakangi oleh istri yang menjadi TKW. Melihat fenomena tersebut, berbeda halnya dengan TKW di Desa Gajah Kecamatan Sambit Kabupaten Ponorogo yang masih ditemukan beberapa unit keluarga TKW yang tetap harmonis meskipun

1 Efrianus Ruli, “Tugas Dan Peran Orang Tua Dalam Mendidk Anak," Jurnal Edukasi Nonformal 1, no. 2 (March 4, 2020): 143-46.

2 Hadi Santoso, "Faktor Penyebab Perceraian Tenaga Kerja Wanita (Tkw) Di Kecamatan Ngantru Kabupaten Tulungagung" 10 (2021): 8.

${ }^{3}$ Arifuddin, Keluarga dalam Pembentukan Akhlak Islami (Yogyakarta: Ombak, 2015), 121.

${ }^{4}$ Hadi Santoso, "Faktor Penyebab Perceraian Tenaga Kerja Wanita (Tkw) Di Kecamatan Ngantru Kabupaten Tulungagung" 10 (2021): 8.

5 "Admin, "Perceraian Di Ponorogo Didominasi Pekerja Migran - Penelusuran Google," accessed August 14

2021, https://www.google.com/search?q=Admin $\% 2 \mathrm{C}+\%$ E2\%80\%9CPerceraian+di+Ponorogo+Didominasi+Pekerja +Migran\&oq=Admin $\% 2 \mathrm{C}+\%$ E2\%80\%9CPerceraian+di+Ponorogo+Didominasi+Pekerja+Migran\&aqs=chrome. .69i57.4224j0j4\&sourceid=chrome\&ie=UTF-8. 
trend nya adalah perceraian yang disebabkan oleh ketidakberfungsian peran dan fungsi keluarga.

Penelitian ini dilakukan tidak terlepas dari hasil penelitian-penelitian terdahulu yang pernah dilakukan sebagai bahan perbandingan dan kajian. Pertama, penelitian Luluk Dwi Kumalasari,' tentang "Keharmonisan Keluarga TKW dalam Perspektif Gender studi di Donomulyo Malang”. Penelitian tersebut menjelaskan terjadinya pergeseran peran, pola kerja dan pola asuh banyak yang menyebabkan terjadinya ketidakharmonisan keluarga. Secara ekonomi memang kebanyakan sukses, tetapi dalam konsep kerukunan, keutuhan rumah tangga, banyak yang bermasalah. Sedangkan dalam penelitian ini keluarga TKW dapat menyelesaikan konflik dan menjalin komunikasi dengan baik sesuai dengan AlQur'an tanpa terjadi pergeseran peran pokok dalam keluarga.

Kedua, penelitian Farichatul Machsuroh,7 tentang "Pertukaran Peran Pencari Nafkah Utama dalam Keluarga (Studi Kasus di Desa Lengkong Kecamatan Sukorejo Kabupaten Ponorogo)". Penelitian tersebut menjelaskan faktor utama yang mendorong pertukaran peran dalam pencarian nafkah adalah karena tirhimpit ekonomi, penghasilan suami yang kurang mencukupinya serta adanya implikasi dari budaya TKW. Tentunya ketika suami istri saling bertukar peran, akan ada dampak yang muncul, dampak tersebut diantaranya adalah istri tidak mau melayani suami, tidak memiliki waktu luang untuk keluarga dan istri akan berperilaku semena-mena kepada suami. Berbeda halnya dengan penelitian ini dimana pasangan tetap mampu mengatasi konflik meskipun dalam kondisi jarak jauh.

Ketiga, Abdul Rohim, ${ }^{8}$ tentang "Pengaruh Istri Bekerja Di Luar Negeri Dalam Mewujudkan Keluarga Sakinah Studi Kasus di Dusun Ringin Desa Payaman Kecamatan Solokuro Kabupaten Lamongan". Penelitian ini menjelaskan pengaruh istri bekerja sebagai TKW dalam mewujudkan keluarga sakinah tersebut lebih

\footnotetext{
${ }^{6}$ Luluk Dwi Kumalasari, "Keharmonisan Keluarga TKW dalam Perspektif Gender studi di Donomulyo Malang", Humanity, no. 2 (2011): 114.

7 Ahwan Fanani, "Model Resolusi Konflik Alternatif Dalam Hukum Islam," Al-Manahij: Jurnal Kajian Hukum Islam 7, no. 2 (January 1, 1970): 271-90, https://doi.org/10.24090/mnh.v7i2.569.), 72

8 Abdul Rohim and M. Ikhwanuddin, "Pengaruh Istri Bekerja Diluar Negeri Dalam Mewujudkan Keluarga Sakinah (Study Kasus TKW di Dusun Ringin Desa Payaman Kecamatan Solokuro Kabupaten Lamongan)," MAQASID 5, no. 1 (February 9, 2018), http://journal.umsurabaya.ac.id/index.php/Maqasid/article/view/1370. 1
} 
banyak pengaruh negatifnya daripada pengaruh positifnya. Sedangkan dalam penelitian keluarga TKW di desa Gajah lebih banyak pengaruh positifnya sehingga mereka tetap mampu mempertahankan keharmonisan keluarganya sesuai dengan ajaran Islam.

Berpijak pada uraian pada latar belakang diatas, bahwa dibalik trend perceraian oleh keluarga TKW masih terdapat keluarga yang tetap harmonis meskipun dihadapkan dengan berbagai konflik, maka penelitian mengambil fokus pertanyaan, terkait: 1) Bagaimana pola komunikasi keluarga TKW di Desa Gajah Sambit Ponorogo pespektif psikologi keluarga Islam? 2) Bagaimana resolusi konflik keluarga TKW di Desa Gajah Sambit Ponorogo perspektif psikologi keluarga Islam?

Untuk mengurai persoalan tersebut, penelitian ini menggunakan penelitian lapangan (field Research) dengan pendekatan empiris. Pendekatan ini diambil karena didasarkan pada obyek penelitian sebagai data primer yang dibutuhkan dalam penelitian yaitu keluarga TKW.

\section{KEHARMONISAN KELUARGA DALAM PERSPEKTIF PSIKOLOGI KELUARGA ISLAM}

Psikologi Keluarga Islam adalah studi yang mempelajari tentang perilaku, fungsi mental, dan proses kejiwaan manusia pada kehidupan keluarga yang didasarkan kepada ajaran Islam. Psikologi keluarga Islam sangat dibutuhkan sebagai acuan dalam penanganan terapi keluarga di lembaga-lembaga klinik terapi seperti Kantor Urusan Agama (KUA), BKKBN, bahkan para hakim di Pengadilan Agama. Tujuan yang dicapai dari psikologi keluarga Islam adalah sebagai upaya untuk menciptakan kehidupan keluarga yang harmonis dan sejahtera. ${ }^{9}$

Psikologi keluarga Islam merupakan kajian baru dalam studi keislaman yang muncul di akhir abad 20. Pengkajian terma ini dilatar-belakangi oleh perkembangan studi psikologi keluarga di Barat yang semakin meluas hingga mewarnai pemikiran akademisi muslim di dunia Islam. Hal ini memicu sejumlah

\footnotetext{
${ }_{9}^{9}$ Ratna Suraiya and Nashrun Jauhari, "Psikologi Keluarga Islam sebagai Disiplin Ilmu (Telaah Sejarah dan Konsep)," Nizham Journal of Islamic Studies 8, no. 02 (December 3, 2020): 153, https://doi.org/10.32332/nizham.v8i02.2697. 153-154
} 
ulama dan sarjanawan muslim untuk melakukan konseptualisasi kajian psikologi keluarga dalam perspektif Islam. ${ }^{10}$

Dalam Islam keharmonisan keluarga dikenal dengan kata sakinah yang terdiri dari mawaddah, dan rahmah. Cinta (mawaddah) adalah perasaan cinta yang melahirkan untuk membahagiakan dirinya. Sedangkan kasih sayang (rahmah) adalah perasaan yang melahirkan keinginan untuk membahagiakan orang yang dicintainya. Pasangan suami istri memerlukan mawaddah dan rahmah sekaligus, yakni perasaan cinta yang melahirkan keinginan untuk membahagiakan dirinya sendiri sekaligus pasangannya dalam suka maupun duka tanpa menyatukan keduanya, akan muncul kemungkinan pasangan suami dan istri hanya peduli pada kebahagiaan dirinya masing-masing atau memanfaatkan pasangan demi kebahagiaan dirinya sendiri tanpa peduli kebahagiaan pasangannya. ${ }^{11}$ Sebagaimana dijelaskan dalam Surah Al-Rūm ayat 21 berikut: "Dan di antara tanda-tanda kekuasaan-Nya ialah Dia menciptakan untukmu isteri-isteri dari jenismu sendiri, supaya kamu cenderung dan merasa tenteram kepadanya, dan dijadikan-Nya diantaramu rasa kasih dan sayang. Sesungguhnya pada yang demikian itu benar-benar terdapat tanda-tanda bagi kaum yang berfikir."12

Dari sudut pandang psikologi keluarga Islam, keberlangsungan hidup keluarga yang harmonis adalah:

a. Prinsip kesepadanan (kafāah) antar pasangan yang sama-sama manusia dengan martabat.

b. Terpenuhinya segala kebutuhan hidup berupa sandang, pangan dan papan.

c. Adanya norma hukum yang mengatur perilaku setiap pasangan. ${ }^{13}$

Pola dapat diartikan sebagai bentuk atau suatu struktur keluarga dalam berinteraksi satu sama lain. Pola juga dapat diartikan sebagai keseluruhan yang terdiri atas beberapa unsur (bagian-bagian, elemen), dimana unsur yang satu dengan yang lainnya saling berhubungan secara korelatif, saling mendukung, saling menopang, saling mengukuhkan dan saling menjelaskan. Selanjutnya

10 Ibid., 155.

11Direktur Bina KUA dan Keluarga Sakinah, Bacaan mandiri calon pengantin (Jakarta: Dirjen Bimas Islam Kemenag RI, 2017), 12.

12 Departemen Agama RI, Al-Qur'an dan Terjemahanya, 210.

13 Suraiya and Jauhari, "Psikologi Keluarga Islam sebagai Disiplin Ilmu (Telaah Sejarah dan Konsep)." 
komunikasi secara etimologi adalah hubungan atau perhubungan. Istilah komunikasi sendiri berasal dari bahasa latin, yaitu "communication" akar kata dari "communis" yang berarti sama atau sama makna dalam suatu hal. ${ }^{14}$

Komunikasi Islami sangat mementingkan komitmen moral atau akhlak yang tinggi seperti yang diajarkan al-Qur'an dan sunnah Nabi Muhammad Saw. keterbukaan dan kejujuran adalah ciri khas komunikasi yang Islami. Al-Qur'an bersifat pesan (firman) Allah yang bersifat imperatif kepada manusia. Demikian juga hadith Nabi merupakan kumpulan pesan (sabda) Rasulullah Saw tentang kehidupan, dalam menjabarkan berbagai pesan Allah dalam al-Qur'an. Etika komunikasi Islam antara lain tergambar dalam hadith Nabi yang berbunyi:

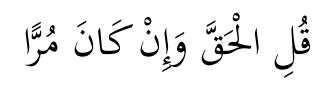

Artinya: Katakanlah apa yang benar sekalipun pahit.

Berkomunikasi yang baik menurut norma agama, tentu harus sesuai pula dengan norma agama yang dianut. Bagi umat Islam, komunikasi yang baik adalah komunikasi yang sesuai dengan nilai-nilai yang terkandung dalam al-Qur'an dan sunnah. Dalam Islam, etika bisa disebut dengan akhlak. Karena itu, berkomunikasi harus memenuhi tuntunan akhlak sebagaimana tercantum di dalam sumber ajaran Islam itu sendiri, jadi kaitan antara nilai etis dan norma yang berlaku sangat erat. Selain agama sebagai asas kepercayaan atau keyakinan masyarakat, maka ideologi juga menjadi tolak ukur norma yang berlaku.

Menurut Imam al-Ghazāli prinsip dasar etika dalam berkomunikasi bagi umat Islam adalah nilai-nilai moral yang terdapat dalam al-Qur'an dan sunnah yang memberikan prinsip dasar yang mendasari etika dalam hal berkomunikasi, di antaranya: ${ }^{15}$

a. Amanah

Aspek kejujuran atau objektifitas dalam berkomunikasi merupakan etika yang didasarkan kepada fakta. Dalam al-Qur'an, kejujuran ini dapat diistilahkan dengan amanah yang artinya tidak menipu. Dalam konteks komunikasi biasa dipahami bahwa ketidakjujuran dalam memberikan informasi akan menimbulkan kegelisahan batin dan hilangnya rasa kepedulian

\footnotetext{
15 Mukhlison Iqbal, "Etika Komunikasi Dalam Islam Telaah Pemikiraan Imam Al-Ghazali” (Dakwah dan Komunikasi, January 12, 2017), https://idr.uin-antasari.ac.id/7441/.39.
} 
sosial. Sebagaimana dijelaskan dalam QS. Al- Nisā' ayat 58 berikut: "Sesungguhnya Allah menyuruh kamu menyampaikan amanat kepada yang berhak menerimanya, dan (menyuruh kamu) apabila menetapkan hukum di antara manusia supaya kamu menetapkan dengan adil. Sesungguhnya Allah memberi pengajaran yang sebaik-baiknya kepadamu. Sesungguhnya Allah adalah Maha mendengar lagi Maha melihat. ${ }^{16}$

b. Tidak melakukan dusta (ghayr al-kidhb)

Sementara etimologi kata kidhb dipahami sebagai lawan kata al-sidiq (benar). Dalam Islam sangat dituntut untuk tidak berdusta sebab akan membawa malapetaka pada orang lain yang menerima suatu informasi. Dari sudut etika komunikasi, maka berbohong merupakan sifat tercela. Kebohongan dalam komunikasi akan menyesuaikan masyarakat disebabkan telah menyerap informasi yang salah. Sebagaimana dijelaskan dalam surat alNahl ayat 16 berikut: "Dan (dia ciptakan) tanda-tanda (penunjuk jalan) dan dengan bintang-bintang itulah mereka mendapat petunjuk."17

c. Adil

Konsep adil dijelaskan sebagaimana yang terdapat dalam surat al-an'ām ayat 152 berikut: "Dan apabila kamu berkata, Maka hendaklah kamu berlaku adil, kendatipun ia adalah kerabat(mu), dan penuhilah janji Allah. yang demikian itu diperintahkan Allah kepadamu agar kamu ingat."18

Dari ayat di atas jelas bahwa umat Islam diperintahkan untuk berkomunikasi dengan adil, artinya berkomunikasi dengan benar, tidak memihak dan tentunya sesuai dengan hak-hak seseorang. ${ }^{19}$ Al-Qur'an telah menampilkan 6 prinsip yang terkandung dalam ayat-ayatnya. Adapun ayat yang menjadi landasan prinsip dalam komunikasi itu adalah:20

16 Departemen Agama RI, Al-Qur'an dan Terjemahanya, 86.

17 Ibid., 163

18 Ibid., 63

19 Muslimah, 'Etika Komunikasi Dalam Perspektif Islam,' Sosial Budaya, No. 2 - Penelusuran Google,” accessed August 14, 2021, https://www.google.com/search?q=Muslimah\%2C+\%E2\%80\%9CEtika+Komunikasi+dalam+Perspektif+Isla $\mathrm{m} \% 2 \mathrm{C} \% \mathrm{E} \%$ 80\%9D+Sosial+budaya\%2C+no.+2\&btnK=Penelusuran+Google\&sxsrf=ALeKk01assQ3t9Jw7ggBx vWfkPdM2YRjVQ\%3A1628921370232\&source=hp\&ei=Gl4XYeGgC_240PEPluO6mAY\&iflsig=AINFCbYAAAAA YRdsKvFxnfwPdAq8L-R0t40LWcv0zJn0. 20Ibid., 135. 
1. Perkataan yang benar (qawlan shadidan)

Hal ini sesuai dalam firman Allah dalam surat Al-Nisā' ayat 9 bahwa "Dan hendaklah takut kepada Allah orang-orang yang seandainya meninggalkan dibelakang mereka anak-anak yang lemah, yang mereka khawatir terhadap (kesejahteraan) mereka. Oleh sebab itu hendaklah mereka bertakwa kepada Allah dan hendaklah mereka mengucapkan Perkataan yang benar."21

Cara penyampaiannya harus menggambarkan kasih sayang dan diungkapkan. dengan kata-kata yang lemah lembut. Selain bermakna juga tepat dan sesuai dengan kondisi psikologisnya.

2. Perkataan yang baik (qawlan ma'rüfan)

Perkatan yang baik dalam berkomunikasi menurut al-Qur'an dijelaskan dalam surat al-Nisā' ayat 5 berikut: "Dan janganlah kamu serahkan kepada orang-orang yang belum sempurna akalnya, harta (mereka yang ada dalam kekuasaanmu) yang dijadikan Allah sebagai pokok kehidupan. Berilah mereka belanja dan pakaian (dari hasil harta itu) dan ucapkanlah kepada mereka kata-kata yang baik."22

Secara bahasa arti ma'rüf adalah baik dan diterima oleh nilai- nilai yang berlaku dimasyarakat. Ucapan yang baik adalah ucapan yang diterima sebagai sesuatu yang baik dalam pandangan masyarakat lingkungan penutur.

3. Perkataan yang efektif (qawlan balighan)

Makna dasar dari ungkapan perkataan yang efektif dapat dipenuhi dalam dua hal yaitu; Pertama, apabila komunikator menyesuaikan pembicaraannya dengan sifat-sifat khalayak yang dihadapinya. Karena itu, Allah mengutus rasulnya sesuai dengan bahasa di mana mereka diutus. Kedua, bila pihak komunikator menyentuh khalayaknya pada hati dan pikirannya sekaligus. Sesuai dengan hasil penelitian, komunikasi

${ }^{21}$ Departemen Agama RI, Al-Qur'an dan Terjemahanya, 46.

22 Ibid, 43. 
menunjukkan bahwa setiap perubahan sikap lebih cepat terjadi dengan adanya himbauan emosional. ${ }^{23}$

4. Perkataan yang mudah dan pantas (qawlan mashüra)

Dalam berkomunikasi, selain menggunakan bahasa yang efektif dan tepat sasaran, seorang penyampai informasi juga dianjurkan untuk selalu menggunakan bahasa yang mudah. Hal ini dimaksudkan agar pihak kedua dapat menangkap pesan-pesan atau informasi secara mudah. Melihat konteks ayat tersebut, maka ungkapan perkataan yang mudah dan pantas merupakan sebuah ungkapan yang membuat orang lain memiliki harapan yang baik serta tidak membuat mereka kecewa. Dengan demikian ungkapan perkataan yang mudah dan pantas dapat memberikan rincian operasional bagi tatacara pengucapan bahasa yang mudah dan bersahaja.

5. Perkataan yang lembut

Perkataan yang lembut dalam al-Qur'an telah dijelaskan dalam surat Tāhā ayat 44 berikut: "Maka berbicaralah kamu berdua kepadanya dengan kata-kata yang lemah lembut, Mudah-mudahan ia ingat atau takut."24

6. Perkataan yang mulia (qawlan kariman)

Perkataan yang mulia ini didalam al-Qur'an dijelaskan dalam surat Al-isrā' ayat 23 berikut: "Dan Tuhanmu telah memerintahkan supaya kamu jangan menyembah selain Dia dan hendaklah kamu berbuat baik pada ibu bapakmu dengan sebaik-baiknya. Jika salah seorang di antara keduanya atau kedua-duanya sampai berumur lanjut dalam pemeliharaanmu, Maka sekali-kali janganlah kamu mengatakan kepada keduanya perkataan "ah" dan janganlah kamu membentak mereka dan ucapkanlah kepada mereka perkataan yang mulia."25

Dari segi bahasa, qawlan kariman berarti perkataan mulia. Perkataan mulia adalah perkataan memberi penghargaan dan penghormatan kepada orang yang diajak bicara. Dengan demikian,

${ }^{23}$ Muslimah, 'Etika Komunikasi Dalam Perspektif Islam,' Sosial Budaya, No. 2 - Penelusuran Google.”

${ }^{24}$ Departemen Agama RI, Al-Qur'an dan Terjemahanya, 168.

25 Ibid., 156 
perkataan yang mulia (qawlan kariman) dapat disimpulkan memiliki pengertian ucapan mulia yang memiliki penghormatan, pengagungan, dan penghargaan terhadap lawan tutur. ${ }^{26}$

Untuk mewujudkan resolusi konflik dalam keluarga sebagaimana yang dipaparkan oleh Wardiansyah bahwasannya Wahbah Al-Zuhayli berpendapat bahwa semua rangkaian resolusi dalam konflik keluarga ditawarkan berdasarkan pada QS. Al-Nisā' ayat 35. Urutan solusi secara runtutan adalah sebagai berikut ${ }^{27}$ :

1. Al-ma'rüf (pergaulan yang santun)

Yakni itikad baik dan upaya sungguh-sungguh kedua belah pihak menciptakan hubungan yang baik. Islam menerapkan asas egaliter (persamaan harkat martabat) antar manusia dalam kehidupan politis, sosial, maupun ekonomi, termasuk dalam kehidupan berumah tangga. ${ }^{28}$

2. Al-Sabr (Kesabaran)

Konsep kesabarana sebagaimana dijelaskan dalam surat alNisā' ayat 19 berikut: "Hai orang-orang yang beriman, tidak halal bagi kamu mempusakai wanita dengan jalan paksa dan janganlah kamu menyusahkan mereka karena hendak mengambil kembali sebagian dari apa yang telah kamu berikan kepadanya, terkecuali bila mereka melakukan pekerjaan keji yang nyata. Dan bergaullah dengan mereka secara patut. kemudian bila kamu tidak menyukai mereka, (maka bersabarlah) karena mungkin kamu tidak menyukai sesuatu, padahal Allah menjadikan padanya kebaikan yang banyak." 29

Dalam konteks kehidupan rumah tangga dimaknai sebagai kesanggupan suami untuk tidak mengeluh dan terburu-buru mengambil vonis terhadap istrinya. Kesabaran dan upaya bertahan menghadapi ujian yang timbul sebagai akibat perkawinan termasuk

26 Rohman Abd, "Komunikasi dalam Al-Qur'an relasi Ilahiyah dan Insaniyah", (UN-Malang press,

27 Fedrik Wardiansyah, "Analisis Pemikiran Wahbah Al-Zuhaily tentang Penyelesaian Konflikasi Rumah Tangga dan Implikasi Hukumnya" (diploma, Universitas Islam Negeri Serang Banten, 2019), http://repository.uinbanten.ac.id/3793/. 126

28 Ibid. 127.

${ }^{29}$ Departemen Agama RI, Al-Qur'an dan Terjemahanya, 49 
sikap pasangan yang nush $\bar{u} z$ dan senantiasa membina istrinya ketika dia melakukan pembangkangan meskipun perintah suami itu ada pada koridor yang ma'rüfdan bukan dalam hal maksiat. Allah menyuruh para suami untuk mendidik istri yang tidak patuh agar menjauhinya dan memukul ringan yang tidak menyebabkan cidera. Jika istri kembali patuh, maka suami tidak boleh lagi melakukan penjauhan dan pemukulan lagi. Istri yang patuh itu dalam istilah al-Qur'an diistilahkan sebagai istri salihah.

\section{Tahammul Al-Ada}

Fungsi utama seorang suami tidak hanya terbatas pada penyediaan biaya hidup dan tempat tinggal, melainkan juga pembinaan rohani dan sopan santun. Berdasarkan seuntai hadith yang artinya: "Dari Muawiyyah Al-Qushairī berkata: bahwa Nabi saw pernah ditanya oleh seorang sahabat tentang "apa saja hak seorang istri terhadap suaminya?" maka Nabi bersabda yang artinya: "Berilah istrimu makan jika kamu makan, berilah dia pakaian jika kamu berpakaian, jangan pernah kamu memukul wajahnya, menjelek-jelekannya, dan jangan pula menjauhinya kecuali di dalam rumah". (HR. Imam Ahmad, Abu Dawūd dan Ibn Majah).

4. Al-Wa'zu (nasehat)

Konsep nasehat sebagaimana dijelaskan dalam surat Al-Nisā' ayat 43 berikut: "Wanita yang kamu khawatirkan nushuznya maka nasehatilah mereka dan pisahkanlah mereka di tempat tidur mereka, dan pukullah mereka." 30

Wahbah Al-Zuhayli menafsirkan kata-kata "maka nasihatilah" sebagai upaya suami memberikan nasihat kepada istrinya dengan hikmah dan kebijaksanaan, dengan ungkapan yang akrab dan lemah lembut, misalnya dengan ungkapan seorang suami kepada istrinya; "Jadilah engkau istri yang salihah yang selalu patuh, dan menjaga diri saat suami tiada di sisimu. Janganlah engkau menjadi istri yang 
membangkang" atau "takutlah engkau kepada Allah pada hak-hak yang wajib terhadapku atas dirimu dan hindarilah kecaman Allah". Dan dengan memberikan penjelasan kepada istri bahwa kedurhakaan. ${ }^{31}$

5. Al-Hajr

Upaya nasihat suami dengan cara membatasi komunikasi terhadap istri dan berpisah ranjang, kondisi ini berlangsung jika nasihat dan wejangan suami tidak dapat membendung kedurhakaan istri, misalnya selalu membangkang bila suami memerintahnya, dan pergi meninggalkan rumah tanpa seizin suaminya. Suami boleh menjauhi tempat tidurnya sesuai kemauan suaminya, semata-mata dengan maksud memberi efek jera atas kedurhakaannya. Rasulullah SAW juga pernah meninggalkan tidur bersama (berhubungan badan) dengan salah satu istrinya selama satu bulan.

6. Irsal Al-Hakamain

Istilah hakamain terdapat dalam surat Al-Nisā' ayat ke-35 dapat dijadikan dasar hukum pelaksanaan kehakiman. Berikut penjelasannya: “Dan jika kamu khawatirkan ada persengketaan antara keduanya. Maka kirimlah seorang hakam dari keluarga laki-laki dan seorang hakam dari keluarga perempuan. Jika kedua orang hakam itu bermaksud mengadakan perbaikan, niscaya Allah memberi taufik kepada suamiisteri itu. Sesungguhnya Allah Maha mengetahui lagi Maha Mengenal."32

\section{POLA KOMUNIKASI DAN RESOLUSI KONFLIK KELUARGA TENAGA KERJA WANITA PERSPEKTIF PSIKOLOGI KELUARGA ISLAM}

\section{A. Pola Komunikasi Keluarga Tenaga Kerja Wanita}

Dalam komunikasi keluarga pesan yang disampaikan dapat berupa informasi, nasehat, petunjuk, pengarahan, maupun meminta bantuan. Komunikasi yang terjadi dalam keluarga merupakan suatu komunikasi yang unik, dan komunikasi yang terjadi didalam keluarga tentu akan melibatkan paling sedikit dua orang yang mempunyai sifat, nilai-nilai, pendapat, sikap, pikiran dan perilaku

\footnotetext{
${ }^{31}$ Abdurrahman, Kompilasi Hukum Islam di Indonesia (Jakarta: Aka Press, 2010), 132.

32 Departemen Agama RI, Al-Qur'an dan Terjemahanya (Semarang: Toha Putra, 1989), 47
} 
yang khas dan berbeda-beda. ${ }^{33}$ Komunikasi yang dilakukan pun secara sistematis, dapat saling mempengaruhi, serta adanya timbal balik antara keduanya atau dengan istilah komunikasi dua arah. ${ }^{34}$

Penerapan sebuah pola komunikasi dalam suatu keluarga sebagai wujud mempengaruhi antara sesama anggota keluarga terhadap proses memberikan motivasi diri. Pola komunikasi keluarga sangat berperan penting dalam pembentukan motivasi diri. Keluarga juga sangat berperan penting dalam mengajarkan dari hal yang terkecil sampai terbesar sekalipun, keluarga dapat membimbing, dapat menentukan prilaku seseorang, bahkan membentuk cara pandang anggota keluarga lain terhadap sesuatu yang dianggap tidak baik. ${ }^{35}$

Pola komunikasi keluarga Islam adalah suatu bentuk komunikasi yang berupa interaksi dimana terdapat dua orang atau lebih yang sedang membangun atau melakukan pertukaran informasi dengan satu sama lain yang pada akhirnya akan tiba dimana mereka saling memahami dan mengerti. Al-Qur'an dan sunnah memberikan prinsip dasar etika dalam hal berkomunikasi yaitu: amanah, jujur dan adil. Berdasarkan hal tersebut maka penulis menganalisis pola komunikasi keluarga TKW di desa Gajah dengan prinsip dasar etika berkomunikasi sebagai berikut:

Pertama, amanah. Sebagaimana dijelaskan dalam surat Al-Nisā' ayat 58, bahwa "Sesungguhnya Allah menyuruh kamu menyampaikan amanat kepada yang berhak menerimanya, dan (menyuruh kamu) apabila menetapkan hukum di antara manusia supaya kamu menetapkan dengan adil. Sesungguhnya Allah memberi pengajaran yang sebaik-baiknya kepadamu. Sesungguhnya Allah adalah Maha mendengar lagi Maha melihat."

Aspek kejujuran atau objektivitas dalam berkomunikasi merupakan etika yang didasarkan kepada fakta. Dalam konteks komunikasi biasa dipahami bahwa ketidakjujuran dalam memberikan informasi akan menimbulkan kegelisahan batin dan hilangnya rasa kepedulian social.

\footnotetext{
33 Siti Rahmah, "Pola Komunikasi Keluarga Dalam Pembentukan Kepribadian Anak," Alhadharah: Jurnal Ilmu Dakwah 17, no. 33 (January 2, 2019): 13, https://doi.org/10.18592/alhadharah.v17i33.2369.

34 Chairunnisa Djayadin and Erni Munastiwi, "Pola Komunikasi Keluarga Terhadap Kesehatan Mental Anak Di Tengah Pandemi Covid-19," n.d., 21.

35 Evi Hafizah, “Pola Komunikasi Keluarga Dalam Membentuk Karakter Anak,” n.d., 14.
} 
Dalam kondisi jarak jauh dibutuhkan komitmen dan saling mempercayai satu sama lain. Berkomunikasi dengan suami setiap memiliki waktu luang menjadi alternatif untuk saling memberikan informasi. Agar rumah tangga tetap harmonis tidak lain harus saling percaya dan saling komitmen dalam menjalin hubungan rumah tangga meskipun dalam kondisi jarak jauh. Jarak bukanlah menjadi penghalang untuk saling bertatap dan saling bertemu meskipun via online. Karena zaman sudah berkembang dengan adanya kemudahan teknologi untuk mengakses berbagai informasi. Selain itu, mengetahui tumbuh kembang anak merupakan amanah untuk mendidik anak. Meskipun dalam kondisi jarak jauh mengontrol anak juga dapat dilakukan oleh orangtua.

Kedua, tidak melakukan dusta. Sebagaimana dijelaskan dalam surat Al-Naḥl ayat 16. ${ }^{36}$ Bahwa "Dan (dia ciptakan) tanda-tanda (penunjuk jalan) dan dengan bintang-bintang itulah mereka mendapat petunjuk."

Dalam Islam sangat dituntut untuk tidak berdusta sebab akan membawa malapetaka pada orang lain yang menerima suatu informasi. Dari sudut etika komunikasi, maka berbohong merupakan sifat tercela. Kebohongan dalam komunikasi akan menyusahkan pasangan karena telah menyerap informasi yang salah.

Memberi kabar setiap hari merupakan hal yang harus tetap terjaga. Selalu terbuka dalam segala hal dan selalu menghubungi satu sama lain. Hal ini merupakan salah satu cara mempertahankan rumah tangga agar tetap harmonis. Selain itu, selalu menyampaikan pendapat secara terbuka dan apa adanya tanpa adanya rekayasa. Pola komunikasi bersama pasangan menjadi seimbang karena adanya kejujuran antar pasangan.

Ketiga, adil. Sebagaimana yang dijelaskan dalam surat Al-an'ām ayat 152, bahwa "Dan apabila kamu berkata, Maka hendaklah kamu berlaku adil, kendatipun ia adalah kerabat(mu), dan penuhilah janji Allah. yang demikian itu diperintahkan Allah kepadamu agar kamu ingat."

Dari ayat di atas jelas bahwa umat Islam diperintahkan untuk berkomunikasi dengan adil, artinya berkomunikasi dengan benar, tidak memihak

36 Ibid., 163. 
dan tentunya sesuai dengan hak-hak pasangan. Berlaku adil dalam memberikan waktu dengan istri dapat dilakukan dengan tetap memberi perhatian-perhatian kepada istri. Oleh karena itu terwujudlah kemesraan antar pasangan meskipun dalam kondisi jarak jauh. Selain itu, bercanda ketika berkomunikasi dan saling perhatian satu sama lain menjadi salah satu cara agar pasangan dapat terhibur. Hal ini termasuk berlaku adil dalam memberikan kasih sayang.

\section{B. Resolusi Konflik Keluarga Tenaga Kerja Wanita}

Dalam sebuah pernikahan tidak selamanya dapat dirasa tenang dan selalu berjalan lancar. Setelah terbentuk sebuah keluarga, berbagai permasalahan pasti akan bermunculan. Hal tersebut bisa menjadi faktor yang dapat menyebabkan keretakan rumah tangga atau perceraian. Sebelum hal yang tidak pernah diharapkan terjadi maka hendaklah setiap pasangan berusaha untuk mencegah dengan memperbaiki hubungan dalam keluarga. Dalam keluarga pastinya pernah mengalami konflik, baik konflik antara istri dengan suami atau konflik antara orangtua dengan anak. Akan tetapi dalam setiap permasalahan yang terjadi pasti ada jalan keluarnya.

Arti penting resolusi konflik saat ini mulai dirasakan umat Islam ketika dunia Islam mengalami hubungan tidak harmonis dengan dunia Barat. Isu radikalisme, terorisme, dan fundamentalisme yang diasosiasikan dengan gerakan gerakan Islam mendorong akademisi muslim untuk mencoba meninjau dan mengangkat kembali resolusi konflik dan upaya perdamaian dalam ajaran Islam. Upaya tersebut dilakukan sebagai upaya untuk mengenal resolusi konflik dalam Islam dan melihat bagaimana Islam juga menyediakan model resolusi konflik dan memiliki kontribusi pagi upaya perdamaian. ${ }^{37}$

Jika ditinjau melalui perspektif resolusi konflik hukum keluarga, maka selesainya suatu perkara perceraian tanpa adanya pihak-pihak yang tersakiti juga bagian dari makna resolusi konflik. Wilayah kerja resolusi konflik hukum keluarga bukan saja tentang bagaimana mempertahankan keutuhan rumah tangga pasangan suami istri, akan tetapi juga dalam makna penyelesaian masalah tanpa masalah. Hal ini sejalan dengan definisi yang dibangun oleh Weitzman dalam Morton and Coleman, di mana resolusi konflik merupakan sebuah tindakan

\footnotetext{
37 Fanani, "Model Resolusi Konflik Alternatif Dalam Hukum Islam.”3
} 
pemecahan masalah bersama (solve a problem together). Begitu juga menurut Mindes, di mana resolusi konflik merupakan kemampuan untuk menyelesaikan perbedaan dengan yang lainnya dan merupakan aspek penting dalam pembangunuan sosial dan moral yang memerlukan keterampilan dan penilaian untuk bernegoisasi, kompromi serta mengembangkan rasa keadilan. ${ }^{38}$

Seperti yang telah saya wawancarai kepada suami dan istri yang sedang dalam kondisi jarak jauh karena istri sedang bekerja di luar negeri yang telah menerapkan resolusi konflik sebagaimana pendapat Wahbah Al-Zuhayli yang menyatakan bahwa resolusi konflik terdapat dalam QS. al-Nisā' ayat 35.

Pertama, Al-ma'rüf (pergaulan yang santun) yaitu kondisi dimana terdapat kelembutan dan kerukunan. Kelembutan dan kerukunan antar pasangan yang saling mengikat untuk menampilkan pelayanan yang baik terhadap pasangan, menahan diri untuk menyakiti pasangannya, tidak menunda penunaian hak bila mampu menyegerakannya, tidak menampakan kekecewaan atas pengorbanan yang dilakukan oleh masing-masing suami istri, penuh kesantunan dalam bertutur kata, dan tidak mengungkit kebaikan yang dilakukan masing-masing serta mengiringi kebaikan dengan kata-kata yang menyakitkan. Apabila terjadi kesalahpahaman antar pasangan dapat saling meminta maaf dan saling menjelaskan tanpa adanya kecanggungan. Saling pengertian, saling mengerti posisi dan saling terbuka, saling jujur, saling menerima, dan saling menguatkan. Ketika terjadi konflik dapat diatasi dengan berbicara pelan-pelan dan musyawarah.

Kedua, Al-sobru(kesabaran), yaitu upaya bertahan menghadapi ujian yang timbul antar pasangan. Selalu berfikir positif terhadap pasangan ketika terjadi konflik, berbicara dengan santun dan tetap bersabar adalah kunci terselesaikannya permasalahan. Saling menjaga ego masing-masing ketika terjadi kesalahpahman. Hubungan akan awet jika masalah dihadapi dengan tenang. Mengalah bukan berarti kalah. Bersabar juga menjadi tanggapan bapak Sarino dalam menghadapi ujian kehidupan rumah tangganya.

38 "Resolusi Konflik Keluarga Berbasis Local Wisdom (Reaktualisasi Filosofi Masyarakat Sulawesi Utara Torang Samua Basudara) | Rajafi | YUDISIA : Jurnal Pemikiran Hukum Dan Hukum Islam," accessed August 12, 2021, https://journal.iainkudus.ac.id/index.php/Yudisia/article/view/2129. 4 
Ketiga, Tahammul Al-Ada, yakni kemampuan suami dan istri untuk saling memahami dan saling menerima pendapat serta tidak ada kecanggungan dalam mengeluarkan pendapat. Jadi jika ada hal yang tidak sesuai harus segera di utarakan, pasangan juga harus ikhlas mendengarkan dan tidak meremehkan. Karena hal kecil bagi satu pihak belum tentu kecil bagi pihak lain dan begitu pula sebaliknya. Di balik rumah tangga yang tenteram ada sikap saling terbuka untuk menyampaikan semua isi perasaan dan tidak meremehkan pendapat masingmasing pasangan.

Keempat, Al-Wa'zu (nasehat), yakni saling memberikan nasihat dengan hikmah dan kebijaksanaan, dengan ungkapan yang akrab dan lemah lembut. Jika salah satu pasangan melakukan kesalahan maka pasangan saling menasehati. Tidak jarang orang tua memberi nasehat kepada anak, memberi pengertian kepada anak, berusaha menguatkan anak ketika ingin menemui ibunya. Ayah sebagai kepala rumah tangga wajib baginya untuk menjaga ketentraman rumah tangga.

\section{PENUTUP}

Pola komunikasi yang terjadi dalam keluarga TKW di desa Gajah berjalan dengan terbuka, jujur dan leluasa dalam berpendapat untuk menyelesaikan permasalahan yang terjadi dalam rumah tangga. Hal ini sesuai dengan al-Qur'an tentang etika berkomunikasi, yaitu: amanah, tidak melakukan dusta dan adil. Sementara resolusi konflik dalam mewujudkan keluarga yang harmonis (sakinah, mawaddah, warohmah) pada keluarga TKW di desa Gajah mengguakan 4 resolusi konflik yang terdapat dalam QS Al-Nisā' ayat 35, yaitu: al-ma'rūf (kelembutan dan kerukunan antara suami dan istri), al-sobru (kesabaran), Tahammul al-Ada (kebebasan dalam menyampaikan dan menerima pendapat pasangan) dan alWa'zu(nasehat).

Penelitian ini diharapkan mampu memberikan suatu manfaat terhadap suatu perkembangan ilmu pengetahuan, menjadi tambahan referensi dalam penelitian selanjutnya dengan tema sejenis dan untuk mendukung serta menguatkan teori-teori yang mengemukakan keharmonisan keluarga TKW yang berhasil mempertahankan rumah tangganya. 


\section{DAFTAR PUSTAKA}

Abd, Rohman. "Komunikasi dalam Al-Qur'an relasi Ilahiyah dan Insaniyah". (UNMalang press, 2007)

Admin, "Perceraian Di Ponorogo Didominasi Pekerja Migran - Penelusuran Google." Accessed August 2021. https://www.google.com/search?q=Admin \%2C+\%E2\%80\%9CPerceraian+di +Ponorogo+Didominasi+Pekerja+Migran\&oq=Admin\%2C+\%E2\%80\%9CPerc eraian+di+Ponorogo+Didominasi+Pekerja+Migran\&aqs=chrome..69i57.4224j $0 \mathrm{j} 4 \&$ sourceid $=$ chrome\&ie $=$ UTF-8.

Abdurrahman. Kompilasi Hukum Islam di Indonesia (Jakarta: Aka Press, 2010).

Admin, "Perceraian di Ponorogo Didominasi Pekerja Migran," akses 27 November 2020," https: //www.google.com/amp/s/radarmadiun.co.id/perceraian-diponorogo-didominasi-pekerja migran/amp/

Arifuddin. Keluarga dalam Pembentukan Akhlak Islami (Yogyakarta: Ombak, 2015.

Bina KUA, Direktur dan Keluarga Sakinah. Bacaan mandiri calon pengantin (Jakarta: Dirjen Bimas Islam Kemenag RI, 2017).

Cholil, Mufidah. Psikologi Wawasan Islam Berwawasan Gender (Malang: UIN Press) Departemen Agama RI, Al-Qur'an dan Terjemahanya (Semarang: Toha Putra, 1989) Djayadin, Chairunnisa, and Erni Munastiwi. "Pola Komunikasi Keluarga Terhadap Kesehatan Mental Anak Di Tengah Pandemi Covid-19," n.d., 21.

Fanani, Ahwan. "Model Resolusi Konflik Alternatif Dalam Hukum Islam." AlManahij: Jurnal Kajian Hukum Islam 7, no. 2 (January 1, 1970): 271-90. https://doi.org/10.24090/mnh.v7i2.569.

Hafizah, Evi. "Pola Komunikasi Keluarga dalam membentuk Karakter Anak". Jurnal Studi Gender dan Anak. no. 1 (2019): 92.

Iqbal, Mukhlison. "Etika Komunikasi Dalam Islam Telaah Pemikiraan Imam AlGhazali." Dakwah dan Komunikasi, January 12, 2017. https://idr.uinantasari.ac.id/7441/.

Kumalasari, Luluk Dwi. "Keharmonisan Keluarga TKW dalam Perspektif Gender studi di Donomulyo Malang", Humanity, no. 2 (2011): 114.

Machsuroh, Farichatul. "Pertukaran Peran Pencari Nafkah Utama dalam Keluarga (Studi Kasus di Desa Lengkong Kecamatan Sukorejo Kabupaten Ponorogo)" Skripsi, Ponorogo, IAIN Ponorogo, 2019)

Muslimah, 'Etika Komunikasi Dalam Perspektif Islam,' Sosial Budaya, No. 2 Penelusuran Google." Accessed August 14, 2021. https://www.google.com/search?q=Muslimah\%2C+\%E2\%80\%9CEtika+Kom unikasi+dalam+Perspektif+Islam $\% 2 \mathrm{C} \% \mathrm{E} 2 \% 80 \% 9 \mathrm{D}+$ Sosial+budaya $\% 2 \mathrm{C}+$ no.+ 2\&btnK=Penelusuran+Google\&sxsrf=ALeKk01assQ3t9Jw7ggBxvWfkPdM2YRj VQ\%3A1628921370232\&source=hp\&ei=Gl4XYeGgC_240PEPlu06mAY\&iflsig $=$ AINFCbYAAAAAYRdsKvFxnfwPdAq8L-R0t40LWcv0zJn0.

Nurul, Hasil Wawancara. Ponorogo 26 November 2020.

Rahmah, Siti. "Pola Komunikasi Keluarga Dalam Pembentukan Kepribadian Anak." Alhadharah: Jurnal Ilmu Dakwah 17, no. 33 (January 2, 2019): 13. https://doi.org/10.18592/alhadharah.v17i33.2369.

Rahmawati dan Muragmi Gazali. "Pola Komunikasi dalam Keluarga." Al-Munzir. no. 2 (2018): 164. 
Resolusi Konflik Keluarga Berbasis Local Wisdom (Reaktualisasi Filosofi Masyarakat Sulawesi Utara Torang Samua Basudara) | Rajafi | YUDISIA : Jurnal Pemikiran Hukum Dan Hukum Islam." Accessed August 12, 2021. https://journal.iainkudus.ac.id/index.php/Yudisia/article/view/2129.

Rohim, Abdul, and M. Ikhwanuddin. "Pengaruh Istri Bekerja Diluar Negeri Dalam Mewujudkan Keluarga Sakinah (Study Kasus TKW di Dusun Ringin Desa Payaman Kecamatan Solokuro Kabupaten Lamongan)." MAQASID 5, no. 1 (February 9, 2018). http://journal.umsurabaya.ac.id/index.php/Maqasid/article/view/1370.

Ruli, Efrianus. "TUGAS DAN PERAN ORANG TUA DALAM MENDIDK ANAK." JURNAL EDUKASI NONFORMAL 1, no. 2 (March 4, 2020): 143-46.

Santoso, Hadi. "Faktor Penyebab Perceraian Tenaga Kerja Wanita (Tkw) Di Kecamatan Ngantru Kabupaten Tulungagung" 10 (2021): 8.

Suraiya, Ratna, and Nashrun Jauhari. "Psikologi Keluarga Islam sebagai Disiplin Ilmu (Telaah Sejarah dan Konsep)." Nizham Journal of Islamic Studies 8, no. 02 (December 3, 2020): 153. https://doi.org/10.32332/nizham.v8i02.2697.

Ulfiah, Psikologi Keluarga Penanaman Hakikat Keluarga dan Penanganan Problematika Rumah Tangga (Bogor: Ghalia Indonesia, 2016)

Wardiansyah, Fedrik. "Analisis Pemikiran Wahbah Al-Zuhaily tentang Penyelesaian Konflikasi Rumah Tangga dan Implikasi Hukumnya." Diploma, UNIVERSITAS $\begin{array}{llll}\text { ISLAM NEGERI SERANG } & 2019 .\end{array}$ http://repository.uinbanten.ac.id/3793/.

(C) 2021 by the authors. Submitted for possible open access publication under the terms and conditions of the Creative Commons Attribution-NonCommercial 4.0 International License (CC BY NC) license (https://creativecommons.org/licenses/by$\mathrm{nc} / 4.0 /)$. 